\title{
Financial Performance and Audit Quality: Comparative Study of Investor Reaction
}

\author{
Deden Tarmidi ${ }^{1 *}$, Giawan Nur Fitria ${ }^{1}$, Zamri Ahmad ${ }^{2}$ \\ ${ }^{1}$ Universitas Mercu Buana, Jakarta, Indonesia \\ ${ }^{2}$ Universiti Sains Malaysia, Penang, Malaysia
}

DOI: $10.36348 / \mathrm{sb} .2019 . v 05 i 12.019$

| Received: 20.12.2019 | Accepted: 27.12.2019 | Published: 30.12.2019

*Corresponding author: Deden Tarmidi

\section{Abstract}

The aim of the company to register its shares in the stock exchange is to get additional funds from investors so that the business continues to grow. The company's financial performance is a factor that is highly considered by investors, but what if the information is not quality based on the audit results from the auditor? This study aims to determine investor reactions to financial performance information and audit quality. The uniqueness of this research is the $2 \times 2$ method between financial performance and quality audit so that this study can produce information about how 1) investor reaction to high financial performance with high audit quality, 2) investor reaction to high financial performance but low audit quality, 3) investor reaction to low financial performance with high audit quality, 4) investor reaction to low financial performance with low audit quality. The results showed that investors only react to high financial performance but low audit quality with negative react, it shows that investors are concerned about audit procedures in assessing the company's financial performance. High company performance but has a low audit quality makes investors pay more attention to the company because the good value is actually considered to be detrimental to investors because of its doubtful quality.

Keywords: Investor Reaction, Financial Performance, Audit Quality.

Copyright @ 2019: This is an open-access article distributed under the terms of the Creative Commons Attribution license which permits unrestricted use, distribution, and reproduction in any medium for non-commercial use (NonCommercial, or CC-BY-NC) provided the original author and source are credited.

\section{INTRODUCTION}

Changing the status of a private company to a public company is based on several reasons, one of which is obtaining funds from investors through buying and selling shares on the exchange so that the company can develop. So as an internal party that knows the ins and outs of the company's internal transactions, management will make various efforts to provide a positive signal to investors in order to participate in the company's investment.

Like the people who do business, on the other hand investors also do not want to be rash in making choices in trading stocks. Some investors consider maximum profits in the form of returns in the short term, while other groups consider stable returns in the long run. Of the two types, investor analysis of the issuer will vary as well as its reaction to information published by the issuer through annual reports and financial reports [1].
Anwaar [2] and Macharia \& Gatuhi [3] found in their study that investors are more interested in buying shares of companies that have good financial performance, so that the information on financial statements will get a positive reaction from investors.

In addition to being prohibited from carrying out policies that can reduce company shares such as tax evasion above, the issuer is also obliged to prepare financial reports in accordance with generally accepted provisions. The presence of an external auditor who has competence and independence is expected to be able to ensure the quality of financial statements in accordance with general standards and provide appropriate information to investors. Some studies state that Big 4 auditors have more competence than Non Big 4 auditors, because of flying hours and the complexity of cases and the large number of auditees scattered in various countries. To maintain the quality of auditor independence, the Government through Government Regulation Number 20 of 2015 concerning the Practice 
of Public Accountants regulates the limitation of Public Accountants in conducting audit services, which is a maximum of 5 years and after that a Public Accountant must be rotated or replaced. Some studies conclude that auditor rotation gives a positive reaction to investors on financial statements published by the company.

With the competence and independence possessed by the auditor, the results of the opinions given on the company's financial statements are considered by investors to be more correct or informative. The auditor's opinion on the preparation of the company's financial statements is used by investors to assess the company's compliance in the process of preparing financial statements, so that the numbers displayed can be analyzed by investors to assess the current and future companies. Then the four types of auditor opinion will get a response from investors to the company's financial statements Doxey [4] and Kausar et al., [5].

Based on the background above, this study aims to analyze investor reactions to financial performance and audit quality. The use of method $2 \times 2$ on financial performance and audit quality is the novelty and uniqueness of this research. With this method, researchers can analyze clearly how investors react to companies with 4 groups of independent variables (ie high and low) the results of the data analysis method. The results of this study can be information and input for companies to pay more attention to the process of preparing a good financial report in addition to financial performance that will be informed to the public so that investors are more confident in the published financial information.

This research is a collaborative study abroad, with the collaboration of researchers from different countries it is expected that the results of this study have extensive discussion in accordance with the conditions of investment at home and abroad.

\section{LITERATURE REVIEW \\ Theoritical Framework Signalling Theory}

Signals are instructions given by one party to another. In conjunction with the theory of signals in the business world, signal is an action taken by the company's internal management to provide instructions to investors regarding the state of the company or future prospects [6].

Entities with good future prospects tend to avoid the sale of shares at this time and prefer to take other actions in advancing the company such as by way of debt even though it exceeds the limited capital structure in accordance with the provisions. Conversely, entities with unfavorable future prospects tend to sell their shares and make certain policies to preen to get investors' attention. So the announcement of the sale of shares by a company is generally a signal that the company's condition is not really good. Because of this signal, when a company often offers new shares, usually the stock price falls because the public has caught a negative signal given by the company.

Brigham and Hauston [7] define signal as an action taken by the company in giving instructions to investors about how management views the company's prospects in the future. Signals provided by the company are circulated in the form of information about what internal management has done in realizing the target of the investor. That way, investors will judge that management has worked well and is performing.

Because of the signal given by company management through information, every information provided has an important meaning for investors regarding its decision in funding or investment through buying and selling shares on the stock. An information essentially presents information, notes or descriptions that have occurred in the past, that are being worked on today and prospects that will occur in the future in connection with company policies in running the company's business.

Broadly speaking signal theory is closely related to the availability of information while financial statements are information about the state of the company from the financial aspects used by investors in making investment decisions. In the market, a company ranking going public is commonly done and based on financial ratio analysis, this is done to facilitate the interpretation of the financial statements published by the company.

The audit in this study is a financial report audit conducted by an external auditor. With the competence and independence possessed by the auditor, the auditor's opinion on the financial statements prepared by the company must be of high quality. Conversely, when the auditor's competence and independence in the financial statement audit process is low, the opinions produced are no longer qualified so that they can mislead investors in making investment decisions.

\section{Investor Reaction}

Reaction is an activity that arises because of an event, besides that the reaction is also defined as repsons or the response of a party to something. The reaction of investors in this study is the investor's response to financial statement information published by the company.

The investor reaction depend on 3 things, namely the ability of investors to analyze information, the ability of companies to provide information and 
information published. When investors have excellent analytical skills, any information received by the company will be responded quickly both positively and negatively. When a company has a capable ability to provide important information to investors, the published information can be easily absorbed by investors and used as an analytical tool in investing in the company. When the information published has reliable quality both in content and publication time, investors will react faster to that information.

Some of the information provided by the company proved to have received mixed reactions from investors. Company policies are like the burden of research on new products [8], advertising costs [9], Corporate Governance [10], tax policies [11] to information regarding audit quality in financial reporting $[12,13]$.

\section{Conceptual Framework and Hypothesis Development}

Investment activities carried out by investors certainly expect a good return in the form of dividends, while dividends will be distributed when the company has sufficient profits and or profits. So how will the management in managing its equity be responded by investors as the party who owns shares in the company. Anwaar [2], Macharia \& Gatuhi [3], and Budiharjo [14] in their study found that financial performance with the indicators in it had an impact on investor reactions positively. Based on this, it is suspected that investors will react positively to high financial performance and react negatively to low financial performance.

Quality audits, especially those carried out by independent parties, make financial reports reliable, because they are free from the interests of Management [15]. The characteristics of the audit committee have a positive effect on firm value significantly [16]. In relation to the preparation of financial statements, auditors who are reliable in the audit process will carry out their audit functions properly so that opinions are generated objectively and can strengthen investor confidence in the company's financial statements. Based on this, it is suspected that investors will react positively to high quality audits and react negatively to low quality audits.

As explained, this study will divide the financial performance and audit quality groups into 2 (two) high and low groups, respectively. Then based on the research framework described earlier, the hypothesis of this study is as follows:

H1. High Financial Performance and High Audit Quality get a positive reaction from investors

H2. High Financial Performance and Low Audit Quality get a negative reaction from investors

H3. Low Financial Performance and High Audit Quality get a positive reaction from investors
H4. Low Financial Performance and Low Audit Quality get a negative reaction from investors

\section{METHODOLOGY}

Population and Sample

Manufacturing companies listed on the Indonesia Stock Exchange in 2013-2017 were used as populations in this study, where the purposive sampling method was used to select the data to be analyzed. Completeness of data from each financial statement account used to measure each variable of this study becomes a criterion in purposive sampling. 335 data's observed and analyzed in 4 groups: 105 data's as HPFHAQ group, 55 data's as HPFLAQ group, 107 data's as LPFHAQ, and 68 data's as LPFLAQ.

\section{Operational Variable}

It is the dependent variable that is analyzed and influenced by the independent variables namely financial performance and audit quality as moderation. Investor Reaction is the investor's response to the financial report information published by the company. This response is implemented in share sale and purchase transactions so that it is reflected in the stock price in the market. Adopting Amoah [17], Huang \& Tompkins [10], and Ittonen [18] measurements of Investor Reaction in this study using CAR 3 days (-1, 0, $+1)$

Adopting the research of Maqbool \& Bakr [19], Prasaad et al., [20], Majanga [21], Yu et al., [22], Ganvir \& Dwivendi [23], Bhat \& Bhattacharya [24], Oyewobi et al., [25], Hall [26], Anwar [2], Afrifa \& Padachi [27], financial performance in this study was measured using ROCE (Return on Capital Employed).

Audit quality measurement adopts previous research, namely using perceived proxy quality (PAQ) such as size firm audit, audit fees, reputation, specialization and audit adjustment [28]. In this study, audit quality measurements adopted the research of Riguen and Jarboul [29], where a proxy for measuring audit quality variables using audit quality index consisting of big 4 , co-statutory auditors, big 4 / costatutory auditors and audit fees which then develop into 8 proxies.

\section{Hypothesis Testing Method}

After the data is obtained from existing sources, then tabulation of data is carried out and what distinguishes this research compared to other studies is the method of $2 . x 2$ on the independent variable that is carried out before the processing of statistical data and analysis of results.

The classic assumption test is done with the help of SPSS statistical software, this process is carried out to see the extent of the quality of the data so that it can be continued in the next process. Regression tests 
were carried out on each independent group with the results of the $2 \times 2$ method on the dependent variable which was carried out on average according to the independent group data. Comparative tests are conducted to see how investors react to 1 group of independent variables compared to other independent variable groups.

\section{RESULT AND DISCUSSION}

Descriptive Analysis

Table-1: Statistic Descriptive

\begin{tabular}{|l|l|l|l|l|l|}
\hline \multicolumn{2}{|l|}{ Group } & HPFHAQ & HPFLAQ & LPFHAQ & LPFLAQ \\
\hline N & & 105 & 55 & 107 & 68 \\
\hline \multirow{4}{*}{ FP } & Min & 0,115072 & 0,105113 & $-0,203316$ & $-0,887489$ \\
\cline { 2 - 6 } & Max & 0,970139 & 0,510452 & 0,104821 & 0,108801 \\
\cline { 2 - 6 } & Mean & 0,238854 & 0,215599 & 0,007442 & $-0,017285$ \\
\hline \multirow{4}{*}{ AQ } & Min & 0,375000 & 0,125000 & 0,375000 & 0,125000 \\
\cline { 2 - 6 } & Max & 0,500000 & 0,250000 & 0,500000 & 0,250000 \\
\cline { 2 - 6 } & Mean & 0,400000 & 0,247727 & 0,393692 & 0,238971 \\
\hline \multirow{3}{*}{ RI } & Min & $-0,075000$ & $-0,063545$ & $-0,115789$ & $-0,095238$ \\
\cline { 2 - 6 } & Max & 0,071429 & 0,129808 & 0,119565 & 0,134228 \\
\cline { 2 - 6 } & Mean & $-0,000002$ & 0,005814 & $-0,003505$ & $-0,006121$ \\
\hline
\end{tabular}

After conducting purposive sampling, found 335 data samples from 67 companies with observations for 5 years. Then the financial performance variable data is divided into two groups of High Financial Performance with a range of ROCE values of 0.105 to 0.970 and Low Financial Performance with a range of ROCE values of -0.887 to 0.104 . Likewise the audit quality variable data is divided into two groups of High Audit Quality with a PAQ value of 0.375 to 0.500 and a group of Low Audit Quality with a PAQ value of 0.125 to 0.250 .

Table-1 explains that the mean of financial performance is 0.238 in HPFHAQ, 0.215 in HPFLAQ,
0.007 in LPFHAQ and -0.017 in LPFLAQ. Whereas the mean of audit quality is 0,400 in HPFHAQ, 0,247 in HPFLAQ, 0,393 in LPFHAQ, and 0,238 in LPFLAQ. That showed each group had a different value after the 2X2 procedure for each independent variable.

After the data is divided into $2 \times 2$ groups, the investor reaction values are grouped according to the independent variable data. In Table-1 it is known that the mean value for investor reaction is $-0,000$ in HPFHAQ, 0.005 in HPFLAQ, -0.003 in LPFHAQ and 0.006 in LPFLAQ.

Goodfit Analysis

Table-2: Goodfit Analysis

\begin{tabular}{|l|l|l|l|l|}
\hline Test & HPFHAQ & HPFLAQ & LPFHAQ & LPFLAQ \\
\hline A. Normality Test & Normal & \multicolumn{4}{l|}{} \\
\hline Sig - Kolmogorov-Smirnov &, 225 &, 820 &, 106 &, 062 \\
\hline B. Autocorrelation Test & \multicolumn{4}{|l|}{ Free of Negative Correlation } \\
\hline Durbin-Watson &, 038 &, 243 &, 030 &, 044 \\
\hline C. Heteroscedasticity Test & Free &, 821 &, 890 &, 245 \\
\hline Sig - FP &, 607 &, 281 &, 325 &, 741 \\
\hline Sig - AQ &, 223 & \multicolumn{5}{|l|}{} \\
\hline D. Multicollinearity Test & Free &, 967 &, 981 &, 773 \\
\hline Tolerance &, 950 & 1,034 & 1,019 & 1,293 \\
\hline VIF & 1,052 & & \\
\hline
\end{tabular}

Based on Table-2 above about good fit analysis explained that data is good because normal, haven't autocorrelation, haven't heteroscedasticity and haven't multicollinearity.

Regression and Comparative Analysis 
Table-3: Regression and Comparative

\begin{tabular}{|l|l|l|l|l|l|l|l|l|}
\hline \multirow{2}{*}{ Variable } & \multicolumn{2}{l|}{ HFPHAQ } & \multicolumn{2}{l|}{ HFPLAQ } & \multicolumn{2}{l|}{ LFPHAQ } & \multicolumn{2}{l|}{ LFPLAQ } \\
\cline { 2 - 9 } & t-stat & p-value & t-stat & p-value & t-stat & p-value & t-stat & p-value \\
\hline FP & $-1,823$ &, 071 & 0,568 &, 572 & 1,156 &, 251 & $-1,222$ &, 226 \\
\hline AQ & $-1,535$ &, 128 & $-5,033$ & $0,000^{* * *}$ & $-0,585$ &, 560 & 1,067 &, 290 \\
\hline FP*AQ & 1,824 &, 071 & $-0,037$ &, 970 & $-1,170$ &, 245 & 1,011 &, 316 \\
\hline $\mathrm{R}^{2}$ &, 032 & &, 344 & &, 015 & &, 028 & \\
\hline Adj. $\mathbf{R}^{\mathbf{2}}$ &, 003 & &, 319 & &,- 014 & &,- 018 & \\
\hline F-Stat & 1,113 & & 13,363 & & 0,518 & & 0,614 & \\
\hline Prob (F-Stat) &, $347^{\mathrm{b}}$ & &, $000^{\mathrm{b}}$ & $* * *$ &, $671^{\mathrm{b}}$ & &, $608^{\mathrm{b}}$ & \\
\hline Observation & 105 & & 55 & & 107 & & 68 & \\
\hline
\end{tabular}

Based on Table-3, it can be explained that investors only reacted significantly to the high financial performance but low audit quality group. This indicates that auditors are more cautious and react more to companies that have good financial performance but have low audit quality. The high value of financial performance is precisely the concern of investors because it is considered misleading or obscure information in predicting the company's financial performance in the future, investors consider companies in the group of high financial performance but low audit quality as a company that needs to be aware of in investors' decision to buy and sell shares compared to other groups.

Based on the statistical results, only hypothesis 2 is accepted while other hypotheses are rejected. This result is in line with Afza \& Nazir's [16] research which found that investors reacted positively to the high quality of audits in the preparation of financial statements, on the contrary that investors reacted negatively to the low quality of audits because they were related to the low quality of information published in financial statements including performance corporate finance.

In the analysis unit of manufacturing companies in Indonesia, investors reacted negatively although not significantly to the group of high financial performance and high audit quality. This result is an anomaly from the existing theory that investors are interested in companies that have good performance and good audit quality. These results are in line with the research of Sarath [30] and Habib [31] who in their research found that good audit quality is not related to the quality of financial statements so that investors are not too responded to. While investors also gave a weak reaction to companies that have low financial performance values but high audit quality and to groups of companies that have low financial performance values and low audit quality. as Alzoubi's research [32] found that audit quality improves the quality of financial statements so that investors respond positively.

\section{CONCLUSIONS}

Based on literature review and finding above, some conclusion found for a clear and simple explanation, as follows:

1. Investors react strongly to companies that publish good financial performance but low audit quality.

2. Investors react weakly to companies that publish high financial performance and high audit quality, low financial performance but high audit quality, low financial performance and low audit quality.

\section{ACKNOWLEDGMENT}

This paper is the result of study on cooperation between the faculty of economics and business Universitas Mercu Buana and Universiti Sains Malaysia. We would like to thank all those who have helped in this study, especially the research center team, the head of the program and the deans and the heads of each university.

\section{REFERENCES}

1. Sunder, S. (2017). Statistical studies of financial reports and stock markets. Journal of Capital Markets Studies, 1(1):5-9.

2. Anwaar, M. (2016). Impact of Firms' Performance on Stock Returns (Evidence from Listed Companies of FTSE-100 Index London, UK). Global Journal of Management and Business Research (D), 16(1):30-39.

3. Macharia, P. I., \& Gatuhi, S. K. (2013). Effect of Financial Performance Indicators on Market Price of Shares in Commercial Banks of Kenya. International Journal of Management \& Business Studies, 3(3):57-60.

4. Doxey, M. M. (2013). The Effect of Increased Audit Disclosure On Investors' Perceptions Of Management, Auditors, and Financial Reporting: An Experimental Investigation. Theses And Disertations - Accountancy Univesity If Kentucky

5. Kausar, A., Taffler, R. J., \& Tan, C. E. L. (2017). Legal Regimes and Investor Response to the Auditor's Going-Concern Opinion. Journal of Accounting, Auditing \& Finance, 32(1):40-72. 
6. Brigham, E. F., \& Ehrhardt, M. C. (2005). Financial Management Theory and Practice, Eleventh Edition, South Western Cengage Learning, Ohio.

7. Brigham, E. F., \& Houston, J. F. (2014). DasarDasar Manajemen Keuangan, Jakarta: Salemba Empat.

8. Li, X., \& Wang, T. (2016). Investor reaction to R\&D investment Are new product announcements and development capacity missing links?. International Journal of Innovation Science, 8(2):133-147

9. Aspara, J., \& Chakravarti, A. (2015). Investors' reactions to company advertisements: the persuasive effect of product-featuring ads. European Journal of Marketing, 49(5/6).

10. Huang, R., \& Tompkins, J. G. (2010). Corporate governance and investor reactions to seasoned equity offerings. Managerial Finance, 36(7):603628.

11. Sikes, S. A., Tian, X. S., \& Wilson, R. (2014). Investors' reaction to the use of poison pills as a tax loss preservation tool. Journal of Accounting and Economics, 57:132-148.

12. Abdallah, S. (2018). External auditor type, discretionary accruals and investors' reactions", Journal of Accounting in Emerging Economies, 2018.

13. Reid, L. C., \& Varcello, J. V. (2017). Investor Reaction to the Prospect of Mandatory Audit Firm Rotation. The Accounting Review, 92(1):183-211.

14. Budiharjo, R. (2019). Effect of Environmental Performance and Financial Performance on Firm Value. International Journal of Academic Research in Accounting, Finance and Management Sciences, 9(2):65-73.

15. Tarmidi, D., \& Murwaningsari, E. (2018). The influence of earnings management and tax planning on firm value with audit quality as moderating variable. Research Journal of Finance and Accounting, 10(4):49-58.

16. Afza, T., \& Nazir, M. Sr. (2014). Audit Quality and Firm Value: a case of Pakistan. Research Journal of Applied Sciences, Engineering and Technology, 7(9):1803-1810.

17. Amoah, N. Y. (2012). Option grants and investor reaction to restatement-induced litigation. Review of Accounting and Finance, 11(1):40-52.

18. Ittonen, K. (2010). Investor reactions to disclosures of material internal control weaknesses. Managerial Auditing Journal, 25(3):259-268.

19. Maqbool, S., \& Bakr, A. (2019). The curvilinear relationship between corporate social performance and financial performance: Evidence from Indian companies. Journal of Global Responsibility, 10(1):87-100.
20. Prasad, P., Sivasankaran, N., Paul, S., \& Kannadhasan, M. (2019). Measuring impact of working capital efficiency on financial performance of a firm: An alternative approach. Journal of Indian Business Research, 11(1):75-94.

21. Majanga, B. B. (2018). Corporate CAPEX and market capitalization of firms on Malawi stock exchange: an empirical study. Journal of Financial Reporting and Accounting, 16(1):108-119.

22. Yu, W., Ramanathan, R., Wang, X., \& Yang, J. (2018). Operations capability, productivity and business performance: The moderating effect of environmental dynamism. Industrial Management \& Data Systems, 118(1):126-143.

23. Ganvir, M. B., \& Dwivedi, N. (2017). Internationalization and performance of Indian born globals Moderating role of presence of foreign equity. International Journal of Emerging Markets, 12(1):108-124.

24. Bhatt, R. R., \& Bhattacharya, S. (2017). Family firms, board structure and firm performance: evidence from top Indian firms. International Journal of Law and Management, 59(5):699-717.

25. Oyewobi, L. O., Windapo, A. O., Rotimi, J. O. B, \& Jimoh, R. O. J. (2016). Relationship between competitive strategy and construction organisation performance: The moderating role of organisational characteristics. Management Decision, 54(9):2340-2366.

26. Hall, J. H. (2016). Industry-specific determinants of shareholder value creation. Studies in Economics and Finance, 33(2):190-208.

27. Afrifa, G. A., \& Padachi, K. (2016). Working capital level influence on SME profitability. Journal of Small Business and Enterprise Development, 23(1):44-63.

28. Chadegani, A., \& Batra, R. C. (2011). Analysis of adhesive-bonded single-lap joint with an interfacial crack and a void. International Journal of Adhesion and Adhesives, 31(6), 455-465.

29. Riguen, R. K., \& Jarboui, A. (2017). Direct and Mediated among Earnings Quality, Book-Tax Differences and the Audit Quality. Journal of Financial Reporting and Accounting, 15(3):293316.

30. Sarath, B. (2016). Audit quality within adverse selection markets. Asian Review of Accounting, 24(1):2-18.

31. Habib, A., \& Jiang, H. (2014). Audit quality and market pricing of earnings and earnings components in China. Asian Review of Accounting, 22(1):20-34.

32. Alzoubi, E. S. S. (2018). Audit quality, debt financing, and earnings management: Evidence from Jordan. Journal of International Accounting, Auditing and Taxation, 30(2018):69-84. 